\title{
Long-Term Arsenic Sequestration in Biogenic Pyrite from Contaminated Groundwater: Insights from Field and Laboratory Studies
}

\author{
Alicia Fischer ${ }^{1}$, James Saunders ${ }^{1}$, Sara Speetjens ${ }^{1}$, Justin Marks ${ }^{2}$, Jim Redwine ${ }^{2}$, Stephanie R. Rogers ${ }^{1} \mathbb{D}$, \\ Ann S. Ojeda ${ }^{1}$, Md Mahfujur Rahman ${ }^{1}$ (D), Zeki M. Billor ${ }^{1}$ and Ming-Kuo Lee ${ }^{1, *(D)}$ \\ 1 Department of Geosciences, Auburn University, 2050 Beard Eaves Coliseum, Auburn, AL 36849, USA; \\ abf0018@auburn.edu (A.F.); saundersja1953@outlook.com (J.S.); ses0076@auburn.edu (S.S.); \\ s.rogers@auburn.edu (S.R.R.); asojeda@auburn.edu (A.S.O.); mzr0065@auburn.edu (M.M.R.); \\ mzb0009@auburn.edu (Z.M.B.) \\ 2 Anchor QEA, Birmingham, AL 35243, USA; jmarks005@gmail.com (J.M.); jredwine@anchorqea.com (J.R.) \\ * Correspondence: leeming@auburn.edu; Tel.: +1-334-844-4898
}

Citation: Fischer, A.; Saunders, J.; Speetjens, S.; Marks, J.; Redwine, J.; Rogers, S.R.; Ojeda, A.S.; Rahman, M.M.; Billor, Z.M.; Lee, M.-K. Long-Term Arsenic Sequestration in Biogenic Pyrite from Contaminated Groundwater: Insights from Field and Laboratory Studies. Minerals 2021, 11, 537. https://doi.org/ $10.3390 / \min 11050537$

Academic Editors: Laura Castro and Maria Luisa Blázquez

Received: 24 March 2021

Accepted: 16 May 2021

Published: 19 May 2021

Publisher's Note: MDPI stays neutral with regard to jurisdictional claims in published maps and institutional affiliations.

Copyright: (c) 2021 by the authors. Licensee MDPI, Basel, Switzerland. This article is an open access article distributed under the terms and conditions of the Creative Commons Attribution (CC BY) license (https:// creativecommons.org/licenses/by/ $4.0 /)$.

\begin{abstract}
Pumping groundwater from arsenic (As)-contaminated aquifers exposes millions of people, especially those in developing countries, to high doses of the toxic contaminant. Previous studies have investigated cost-effective techniques to remove groundwater arsenic by stimulating sulfate-reducing bacteria (SRB) to form biogenic arsenian pyrite. This study intends to improve upon these past methods to demonstrate the effectiveness of SRB arsenic remediation at an industrial site in Florida. This study developed a ferrous sulfate and molasses mixture to sequester groundwater arsenic in arsenian pyrite over nine months. The optimal dosage of the remediating mixture consisted of $5 \mathrm{~kg}$ of ferrous sulfate, $\sim 27 \mathrm{~kg}$ ( $60 \mathrm{lbs}$ ) of molasses, and $\sim 1 \mathrm{~kg}$ (2 lbs) of fertilizer per $3785.4 \mathrm{~L}$ (1000 gallons) of water. The remediating mixture was injected into 11 wells hydrologically upgradient of the arsenic plume in an attempt to obtain full-scale remediation. Groundwater samples and precipitated biominerals were collected from June 2018 to March 2019. X-ray diffraction (XRD), X-ray fluorescence $(\mathrm{XRF})$, electron microprobe (EMP), and scanning electron microscope (SEM) analyses determined that As has been sequestered mainly in the form of arsenian pyrite, which rapidly precipitated as euhedral crystals and spherical aggregates (framboids) 1-30 $\mu \mathrm{m}$ in diameter within two weeks of the injection. The analyses confirmed that the remediating mixture and injection scheme reduced As concentrations to near or below the site's clean-up standard of $0.05 \mathrm{mg} / \mathrm{L}$ over the nine months. Moreover, the arsenian pyrite contained $0.03-0.89$ weight percentage (wt $\%$ ) of sequestered arsenic, with $>80 \%$ of groundwater arsenic removed by SRB biomineralization. Considering these promising findings, the study is close to optimizing an affordable procedure for sequestrating dissolved As in industry settings.
\end{abstract}

Keywords: arsenic; bioremediation; SRB; arsenian pyrite; groundwater; geochemistry

\section{Introduction}

Arsenic (As) contamination of groundwater is one of the most pervasive health hazards worldwide [1]. Arsenic is categorized as an International Agency for Research on Cancer (IARC) Group 1 carcinogen [2]. High exposure to the toxic metalloid causes arsenicosis, which induces skin lesions, diabetes, peripheral neuropathy, cardiovascular disease, cancers of the skin, bladder, and lungs, and a higher risk of preterm and stillborn births [1]. Considering the soluble nature of arsenic, water-rock interactions such as weathering of As-sulfide minerals present in the sediment (e.g., orpiment $\left(\mathrm{As}_{2} \mathrm{~S}_{3}\right)$ and realgar (AsS)) and bacterial-mediated reduction of As-rich iron (Fe) and manganese (Mn) oxides commonly release arsenic into water bodies, including aquifers used for drinking water and irrigation [3-7]. 
While geogenic arsenic contamination is well known in regions like the Bengal Basin, anthropogenic sources of arsenic contamination, common at industrial and agricultural sites in developed regions, can also be a threat to groundwater quality $[8,9]$. Most anthropogenic arsenic originates from the use of herbicides, pesticides, and other agricultural aids $[10,11]$. Arsenical herbicides are soluble in water, allowing arsenic to accumulate in aquifers over time. Although arsenical herbicides and pesticides have been phased out beginning in the 1980s and barred from use by the U.S.A. Environmental Protection Agency (EPA) in 2009 [12], legacy contamination from industrial manufacturing sites and extensive field applications still pose a threat to groundwater quality today. Given this dilemma, the development of As-remediation techniques is of high importance world-wide.

Many arsenic-removal techniques have been developed, but most use ex-situ remediation, which has shown limited success in remediating arsenic in regard to broad scale field applications [13]. The traditional ex-situ remediation method requires pumping out large volumes of groundwater for treatment on the surface, before being reinjected into the aquifer. Considering this process, most ex-situ methods take a considerable amount of time (typically years) to fully remediate the groundwater in the aquifer [14]. As such, these methods cannot reduce arsenic concentrations in a reasonable timeframe for those suffering from arsenic contamination, such as in several weeks or months [14]. However, the biggest disadvantage of ex-situ remediation is that these techniques are expensive, making them inaccessible for use in developing communities [13].

In-situ methods typically involve injecting a remediating mixture to reduce arsenic and are more effective and affordable for remediating groundwater arsenic contamination. For example, Huerta-Diaz and Morse [3] discovered that anoxic water systems with high levels of sulfate reduction and organic matter along with low levels of iron and sedimentation engender the pyritization of most trace metals. Moreover, they quantified arsenic's high degree of trace-metal pyritization (DTMP), which indicated that arsenic adsorbs onto pyrite [3]. Considering these findings, Saunders et al. [15] proposed the concept of groundwater arsenic remediation by stimulating sulfate-reducing bacteria (SRB). SRB are common in anaerobic seawater, sediment, and aquifers, where they degrade organic materials $[16,17]$. Saunders et al. [15] as well as this study seek to leverage the ubiquity of SRB to promote bioremediation of water-borne contaminants. A ferrous sulfate $\left(\mathrm{FeSO}_{4}\right)$ injection engenders reducing conditions, providing the indigenous SRB with optimal growing conditions to biomineralize pyrite $\left(\mathrm{FeS}_{2}\right)$ [15]. Although both biological and abiological mechanisms have been established experimentally for pyrite formation, microbial-mediated transformation has been shown to be more efficient in converting FeS minerals (e.g., mackinawite, troilite) and $\mathrm{H}_{2} \mathrm{~S}$ into pyrite $[18,19]$. Because pyrite has a notable affinity for arsenic [3] and is stable in aquifers under reducing conditions [20], arsenic is adsorbed onto pyrite's crystalline structure, creating arsenian pyrite $\left(\mathrm{FeS}_{1.99} \mathrm{As}_{0.01}\right)$ and effectively removing dissolved As from the groundwater $[15,21]$. Arsenian pyrite is resistant to shifting redox conditions and, as such, will remain stable and prevent the re-release of arsenic into the aquifer [22,23]. Additionally, SRB are active in groundwater with $<7 \mathrm{pH}$ and reducing conditions $(<0 \mathrm{mV})$ in the presence of iron and sulfate to stabilize the arsenian pyrite [24,25].

Recently Pi et al. [13] demonstrated the success of field SRB bioremediation in an in-situ experiment in Datong Basin, northern China. The field-scale remediation demonstrated that the ferrous sulfate injection removed as much as $77 \%$ of the arsenic in the aquifer, decreasing concentrations from $0.593 \mathrm{mg} / \mathrm{L}$ to $0.136-0.150 \mathrm{mg} / \mathrm{L}$ after multiple injections for 25 days. However, Pi et al. [13] were unable to determine whether the bioprecipitated arsenian pyrite, mackinawite, or other $\mathrm{Fe}$ (II) sulfide minerals sequestered the arsenic. Moreover, this short-term study did not demonstrate the long-term success of SRB bioremediation, nor did it reduce arsenic concentrations to past national standards of $0.05 \mathrm{mg} / \mathrm{L}$ or to the World Health Organization (WHO) standard of $0.01 \mathrm{mg} / \mathrm{L}[1,13,21]$.

This study presents a nine-month SRB-bioremediation experiment at an As-contaminated industrial site in Florida, testing the hypothesis that arsenian pyrite will precipitate and sequester arsenic to reach the site standard of $0.05 \mathrm{mg} / \mathrm{L}$ As. This site clean-up goal was 
chosen of $0.05 \mathrm{mg} / \mathrm{L}$ As established during remediation efforts in the 1990s [11,21], which is higher than the current EPA drinking water standard at $0.01 \mathrm{mg} / \mathrm{L}$. The SRB remediation procedure must demonstrate bioremediation over several months or years and comply to minimum contamination standards to become a reasonable avenue for As bioremediation. As such, this study presents a nine-month, SRB-bioremediation experiment at an Ascontaminated site in Florida, testing the hypothesis that arsenian pyrite will precipitate and sequester arsenic to reach the site standard of $0.05 \mathrm{mg} / \mathrm{L}$. The study's main objectives are to amend the aquifer using an iron sulfate and molasses (organic carbon source) mixture, determine the mineralogy and geochemistry of the As-sorbed Fe-S solids formed by SRB bio-mineralization, and demonstrate the stability of the Fe-S biominerals for long-term As bioremediation. Additionally, this experiment utilizes a new injection strategy: the injection wells were placed hydrologically upgradient of the site, allowing the newly developed ferrous sulfate and molasses injectate to travel downgradient for site remediation.

\section{Materials and Methods}

\subsection{Study Site}

The study developed an in-situ arsenic bioremediation procedure to sequester arsenic for over nine months at an arsenic-contaminated industrial site in northwest Florida (Figure 1). The industrial site's aquifer belongs to the Surficial Aquifer System of Florida, which is predominantly composed of quartz-rich sand and sandy clay that extend to $6.0-7.6 \mathrm{~m}$ below the ground surface (bgs) [11]. The aquifer has moderately oxidizing conditions and a shallow water table that averages $\sim 1.5 \mathrm{~m}$ in depth, with the general groundwater flow direction to the west and northwest at a rate of about $20 \mathrm{~m} /$ year [11].

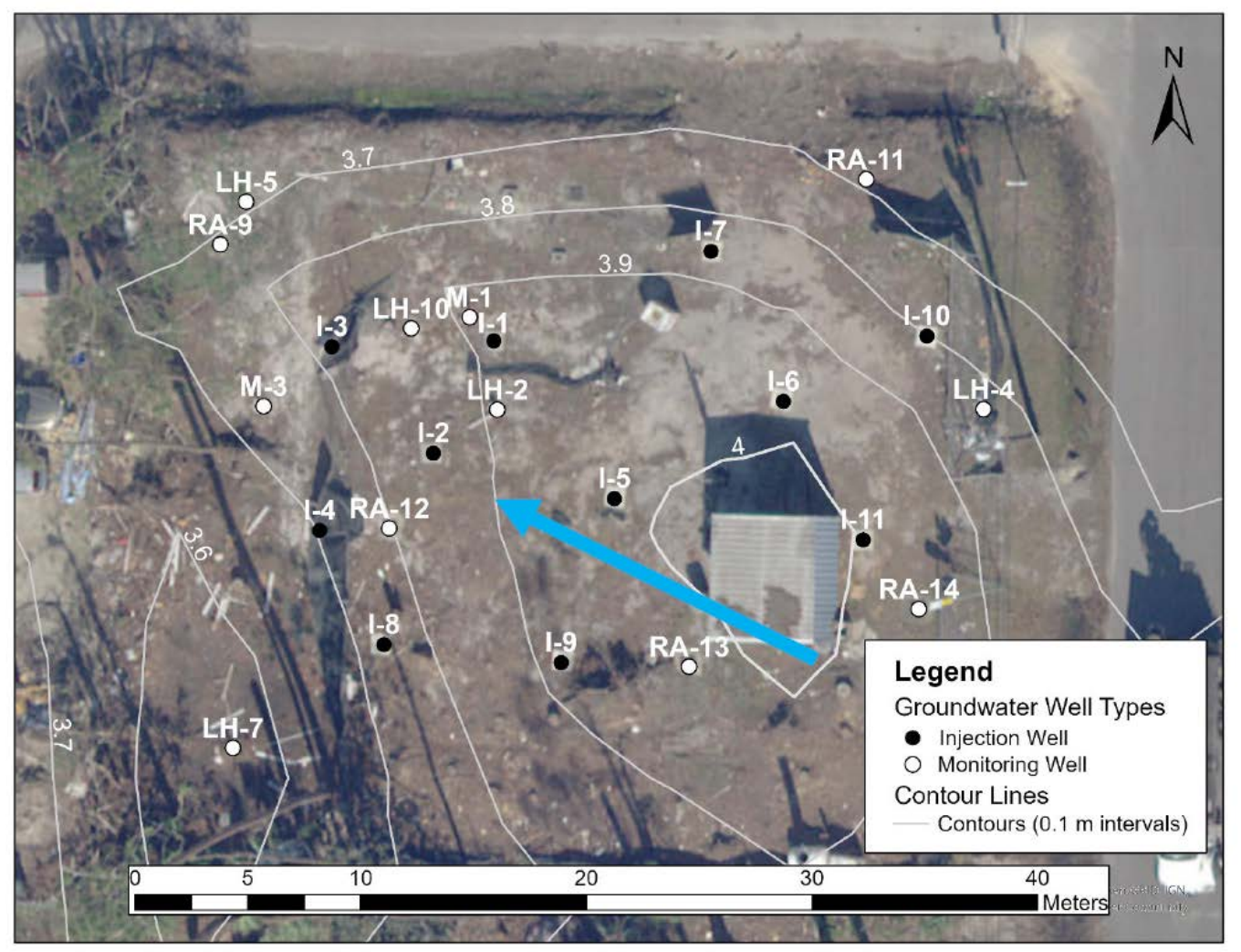

Figure 1. Aerial view of study site in northwest Florida overlayed with the groundwater elevation contour lines (0.1 m intervals), injection wells (in black), and monitoring wells (in white). Groundwater flow direction is shown by the light blue arrow. Modified from Fischer et al. [26].

The aquifer became contaminated with As from the extensive use of arsenical herbicides prior to 1990 [11]. From 1983 to 1993, groundwater quality tests measured arsenic 
levels above the site clean-up limit of $0.05 \mathrm{mg} / \mathrm{L}$ across and outside the site, with the highest arsenic concentrations reaching about $4.5 \mathrm{mg} / \mathrm{L}$ [21]. Ex-situ remediation was quickly utilized to remove the arsenic, removing $\sim 590 \mathrm{~m}^{3}$ of contaminated soil in 1992 and pumping out groundwater for external treatment [21,27]. Although arsenic was reduced by $40 \%$, concentrations remained well above the clean-up standards after the treatment at 0.3 to $>1.0 \mathrm{mg} / \mathrm{L} \mathrm{As} \mathrm{[21].} \mathrm{Due} \mathrm{to} \mathrm{the} \mathrm{ineffective} \mathrm{ex-situ} \mathrm{remediation,} \mathrm{remediation} \mathrm{efforts}$ onsite ceased in 1999 [11,21].

The arsenic contamination was confined in the Surficial Aquifer on site [28]. The Jackson Bluff Formation, which is primarily composed of clay, acts as a confining unit, preventing the flow of groundwater deeper into underlying hydrostratigraphic units and aquifers. The confined nature of the groundwater arsenic in the surficial aquifer aids in current remediation efforts [28].

This study builds upon previous injection strategies at the same study site by Lee et al. [11] and Wilson [29], who used two injection wells (located near the center of the contaminant plume) and eight monitoring wells (three of which were upgradient of the injection wells) to promote SRB-arsenic remediation. These previous studies were proof of concept, small field-scale investigations to determine whether the injection would have any success in this aquifer. By contrast, this study is considered full-scale bioremediation. The scale was increased (11 injection wells and 12 monitoring wells) to include the entire site lot as well as delineate and treat the plume in the northwest corner of the site that was not addressed by the previous studies. Based on the previous studies, new injection sites located hydrologically upgradient of the plume were selected to allow the injectate to target the plume downgradient. Additionally, more monitoring wells were installed for this study downgradient of the injection wells to demonstrate full scale remediation of the plume at the site. Moreover, the injection wells are screened over the entire saturated thickness of the surficial aquifer, which extends down to the top of underlying confining layer Jackson Bluff Formation. This would allow the injectate to reach the contaminated groundwater downgradient. The two monitoring wells upgradient of the injection wells were used to determine groundwater flow directions and the influx of untreated aerobic groundwater over time.

An injectate consisting of $5 \mathrm{~kg}$ of ferrous sulfate (Verdesian Diamond Brand, Standard Ferrous Sulfate Monohydrate), $27 \mathrm{~kg}$ (60 lbs) of molasses (Double S Liquid Feed 79.5 Brix Cane Molasses, 471-100-D), and $1 \mathrm{~kg}$ (2 lbs) of fertilizer (ProCare Premium 10-10-10 All Purpose Fertilizer) per 3785.4 L (1000 gallons) of water [11,21,30]. In the pilot study [11], the $5 \mathrm{~kg}$ of ferrous sulfate mixture was determined to be more effective compared to $2.5 \mathrm{~kg}$ of ferrous sulfate mixture in sequestering arsenic. The addition of molasses in this injection is also critical to promote SRB respiration, and thus biomineralization [11]. The agricultural-grade all-purpose fertilizer-which contained $10 \%$ of nitrogen, phosphorus, and potassium - was included in the injectate, providing additional limiting nutrients to stimulate SRB biomass production and metabolism.

Evidence for SRB metabolism also comes from isotopic and phylogenic evidence in previous studies at the field site [11]. Treated groundwater became enriched in $\delta^{34} \mathrm{~S}$-sulfate (range from 2.02-4.00\%o) compared to unaffected well water (0.40-0.61\%o). Aqueous slurry samples collected from treated groundwater were assessed by real-time polymerase chain reaction (PCR) targeting the apsA gene [31]. The results showed significantly higher numbers (approximately 3Log10 copies/ $\mu$ l) of SRB DNA after injection. The microbial analysis show that Desulfovibrio spp. and Desulfotomaculum spp. could be the functional sulfate-reducing bacteria enhanced by the amendment of organic carbon. Together, these lines of evidence point to SRB active in the groundwater post-injection.

The ferrous sulfate and molasses mixture was injected into 11 injection wells located hydrologically upgradient of the site during the week of 17 June 2018, allowing the injectate to travel downgradient for full-scale site remediation across the $\sim 900 \mathrm{~m}^{2}$ site. From June 2018 to March 2019, groundwater samples and the precipitated biominerals were collected from 11 injection and 12 monitoring wells (Figure 1) weekly for the first four weeks, 
monthly for the first three months, and quarterly for the remaining months. The samples were collected using a peristaltic pump and sand bags. Because the newly formed pyrite tends to sink in groundwater, the collection of colloidal particles periodically from the bottom of wells with a peristaltic pump was used to assess how much biogenic pyrite has formed since the preceding sampling event. Sand-bag sampling was used to examine what new precipitates formed and attached to the sediments (mostly silicate phases) from the aquifer. Two sand bags containing clean quartz sand were installed in selected wells. One bag was located approximately 1 to 2 feet above the bottom of the well, and the other was located 2 to 4 feet below the groundwater surface. The sand bags were pulled and observed during each subsequent sampling event. Figure S1 shows a sand bag prior to installation and two sand bags that had precipitated solids formed during the pilot test monitoring process. The black precipitates observed were examined by XRD and XRF analysis to examine the minerals formed.

Groundwater samples were also collected one month prior to the injection for baseline information. A YSI 556 Multiprobe unit (YSI Inc., Yeros Springs, OH, USA) measured the groundwater temperature, electrical conductivity, $\mathrm{pH}$, oxidation-reduction potential $(\mathrm{ORP})$, and dissolved oxygen (DO) concentrations onsite during each collection period (Tables S1, S2, and S3).

\subsection{Spatial and Temporal Concentration Analyses}

Groundwater samples were filtered with Geotech $0.45 \mu \mathrm{m}$ filter capsules, acidified to a $\mathrm{pH}$ below 2 by $\mathrm{HNO}_{3}$, and stored in polyethylene bottles before being sent to TestAmerica and Auburn University for elemental analyses. Additionally, geographic information systems (GIS) was used to visualize changes in arsenic concentrations spatially and temporally [26].

Groundwater samples were prepared for geochemical analysis by dewatering the samples to obtain the precipitated solids. The samples were centrifuged for $15 \mathrm{~min}$ at 4700 rotations per minute (rpm). The separated solid material was stored at $-20{ }^{\circ} \mathrm{C}$ to preserve their composition while awaiting geochemical analysis. Before the analysis, samples were placed in petri dishes to thaw and dry without exposure to sunlight, considering that natural light can induce the oxidation of arsenite from the photoreduction of Fe(III) [32]. This preparation protocol ensured that the precipitated biominerals were safely preserved for months [33].

\subsection{Mineralogical and Geochemical Analyses}

$\mathrm{X}$-ray diffraction (XRD) and X-ray fluorescence (XRF) assessed the mineralogical and geochemical composition of the biomineralized solids, while the electron microprobe (EMP) quantified the arsenic content in the biogenic sulfide minerals that formed.

A Bruker D2 PHASER X-ray Diffractometer (Bruker, Billerica, MA, USA) was used to determine the mineralogy of the bio-precipitated solids. The sediment samples were separated using a 30-mm sieve to increase the fraction of biogenic iron sulfide minerals, as these form at the micron scale. The solids were analyzed over 5-75 theta for an hour and for one second at each point using the DIFFRAC.EVA software (version 4.2.2.3). The software translates the spectra peaks to d-spacings, which can be matched to specific minerals in the database, allowing the study to identify the minerals that precipitated from SRB bioremediation [29].

A Bruker Tracer IV-SD handheld X-ray fluorescence analyzer was used to ascertain the elemental composition of the solid samples. The sieved and powdered solids were placed into polyethylene XRF sample cups for analysis. The XRF red filter (filter 1) was used for the elemental analyses, which utilizes $12 \mathrm{mil}\left(0.012^{\prime \prime}\right) \mathrm{Al}$ in layer 1, $1 \mathrm{mil}\left(0.001^{\prime \prime}\right)$ $\mathrm{Ti}$ in layer 2, and $1 \mathrm{mil}\left(0.001^{\prime \prime}\right) \mathrm{Cu}$ in layer 3 and a $40 \mathrm{keV}$ tube voltage with the vacuum turned off [34]. The red filter is the recommended way for the instrument to analyze arsenic because the filter uses the 14-40 keV energy range of X-rays that excite arsenic in the samples [34]. The solids were analyzed for $5 \mathrm{~min}$ to stabilize the energy peaks and 
decrease noise. The software matches these energy peaks to specific elements, allowing the study to identify the key elements of $\mathrm{As}, \mathrm{Fe}$, and $\mathrm{S}$ in the samples.

Furthermore, a JEOL 8600 electron microprobe (JEOL, Tokyo, Japan) was used to quantify the arsenic sulfide minerals that precipitated in the groundwater at the micron scale [35]. Thin sections of samples from injection well I-3 two weeks post-injection and from monitoring well RA-9 two months post-injection were analyzed with the EMP. Additionally, gold sputter-coated stubs of I-2 throughout the experiment duration were analyzed. The EMP allowed the study to identify compositional changes and heterogeneity in the minerals throughout the bioremediation procedure. Moreover, the Advanced Microbeam EMP software used As, Fe, and S standards to discern the pyrite grains and quantified the arsenic adsorbed to these minerals as weight percent (wt \%) [35].

\subsection{Imaging and Modeling Analyses}

A scanning electron microscope (SEM) imaged the precipitated biominerals throughout the bioremediation process, while chloride in the remediating mixture was used to assess the injectate arrivals. Additionally, Geochemist's Workbench (GWB, Version 11.0.8) modeled the stability of sulfide minerals using measured field Eh and $\mathrm{pH}$ values and the minerals' saturation indices (SI).

A Zeiss EVO 50VP scanning electron microscope (SEM) (Carl Zeiss AG, Oberkochen, Germany) was used to image the bio-precipitated minerals after the injection. A thin section of sample I-2 two weeks post-injection as well as gold-coated stubs of I-2 over the experiment duration were analyzed with the SEM. The geochemical composition of the minerals was verified using INCA energy dispersive spectroscopy (EDS). The SEM allowed the study to determine the abundance of biogenic pyrite throughout the bioremediation process, along with any physical changes in size, composition, and texture.

Conservative tracers such as chloride are excellent indicators of advective transport, as they migrate in the groundwater through advection and diffusion and have limited attenuation from biogeochemical processes or the surrounding media. To determine the arrival of the remediating injectate in the downgradient monitoring wells, the remediating mixture contained $240 \mathrm{mg} / \mathrm{L}$ chloride as a byproduct of fertilizer to act as a conservative tracer of groundwater flow. The study used spikes of chloride to determine the arrival times of the injectate at each well throughout the site and to compare the measured arrivals to calculated arrivals using the known aquifer properties.

Geochemist's Workbench allowed the study to compute the saturation index (SI) of sulfide minerals and determine whether these minerals were favored to precipitate in the aquifer over the bioremediation procedure. Additionally, the software was used to project the groundwater Eh and $\mathrm{pH}$ values into As-speciation diagrams and predict the thermodynamically stable minerals that would precipitate under these conditions [36].

\section{Results}

\subsection{Spatial and Temporal Concentration Analyses}

Arsenic concentrations showed significant spatial and temporal changes over the nine months following the ferrous sulfate and molasses injection. Prior to injection, arsenic was measured above the site clean-up standard in 14 of the $23(61 \%)$ of the wells, with the contamination plume likely located in the northwest section of the site (Figure 2a; Table S4). Findings from Fischer et al. [26] indicated the 23 wells could be grouped into three categories based on their resultant changes in As: (1) decreasing, (2) fluctuating, or (3) largely unaffected. Of the four wells (LH-4, LH-10, M-1, and RA-9) that showed continuously decreasing arsenic concentrations, three (LH-10, M-1, and RA-9) were in the northwest around the arsenic plume, downgradient of groundwater flow (Figure 1). Most of the wells $(12 / 23)$ showed large arsenic fluctuations (I-1, I-2, I-3, I-4, I-5, I-6, I-7, I-11, LH-2, LH-5, M-3, and RA-12), with many experiencing a significant decrease in arsenic within one month, but then steadily increasing in arsenic over the remaining months (I-1, 
I-2, I-3, I-4, and I-11). The wells that were largely unaffected maintained negligible arsenic concentrations throughout the experiment [26].

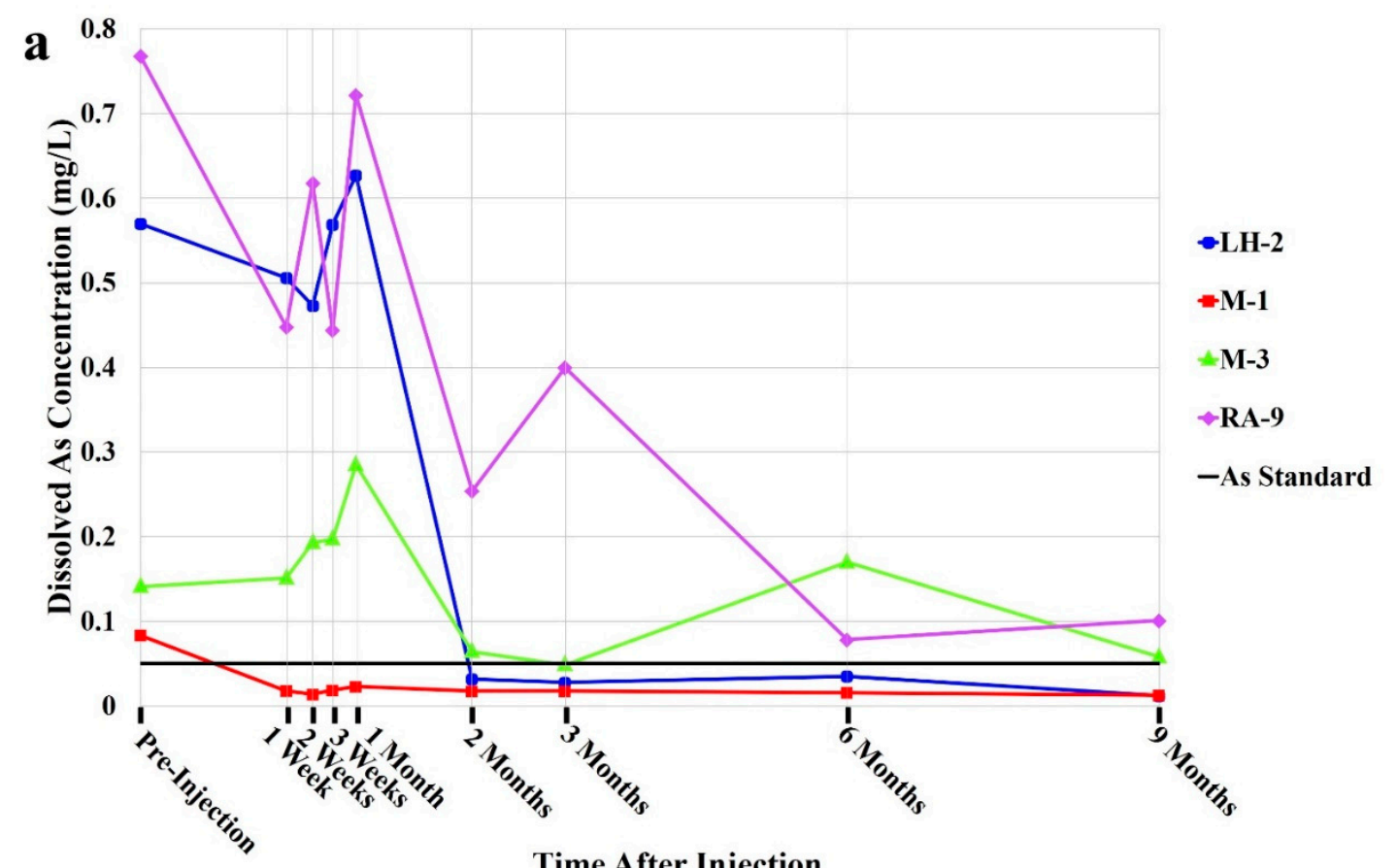

Time After Injection

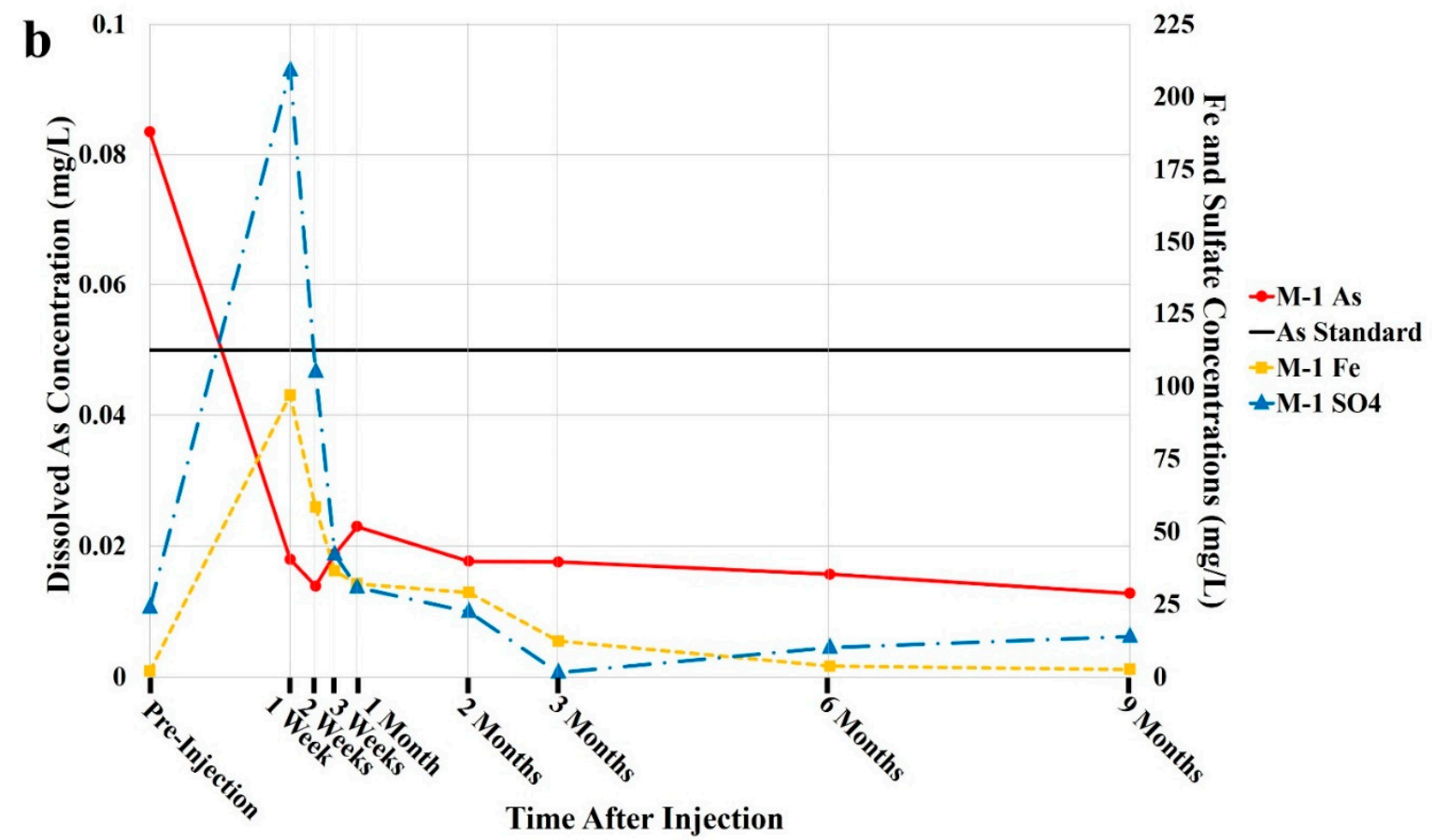

Figure 2. Time series data of (a) dissolved arsenic concentrations in four selected monitoring wells and (b) dissolved arsenic, iron, and sulfate concentrations in monitoring well M-1. Arsenic concentrations were measured using EPA Method 6020 (Inductively Coupled Plasma-Mass Spectrometry).

Overall, As concentrations largely decreased across the site after bioremediation. Arsenic levels decreased in $57 \%$ of the wells over the first month, with $48 \%$ of the wells containing As concentrations $>0.05 \mathrm{mg} / \mathrm{L}$. Arsenic levels slightly increased from one month to nine months, with $52 \%$ of the wells displaying concentrations $>0.05 \mathrm{mg} / \mathrm{L}$ after nine months. Of the wells that were measured with arsenic above the clean-up standard 
before the injection, two wells (LH-2 and M-1) decreased below $0.05 \mathrm{mg} / \mathrm{L}$ after nine months of bioremediation (Figure 2a). As such, these two monitoring wells, with the potential consideration of M-3 and RA-9, are best-case scenarios for demonstrating the success of the remediating procedure (Figure 2a) [26]. Overall, the injection reduced arsenic concentrations below the clean-up standard in 12 wells after one month and 11 wells after nine months, with arsenic levels notably decreasing from 0.17 to $0.08 \mathrm{mg} / \mathrm{L}$ in the monitoring wells.

Compared to arsenic (As), iron ( $\mathrm{Fe})$, and sulfate $\left(\mathrm{SO}_{4}\right)$ concentrations increased after the injection and then steadily decreased over the remaining nine months, whereas $\mathrm{pH}$ and ORP decreased then increased over the nine months. Iron and sulfate swiftly increased from an average of $<2 \mathrm{mg} / \mathrm{L}$ iron and $<20 \mathrm{mg} / \mathrm{L}$ sulfate to $>50 \mathrm{mg} / \mathrm{L}$ iron and $>75 \mathrm{mg} / \mathrm{L}$ sulfate after one week of biostimulation (Figure 2b; Tables S5 and S6). These elevated concentrations were maintained for the first month of the experiment, and then iron and sulfate slowly decreased over the remaining nine months to an average of $1-10 \mathrm{mg} / \mathrm{L}$ iron and $1-10 \mathrm{mg} / \mathrm{L}$ sulfate (Figure $2 \mathrm{~b}$ ). Groundwater $\mathrm{pH}$ was slightly acidic (5.50-6.75) before the injection, which decreased to $<5.25$ in one-third of the wells after one week of the injection (Table S1). Then, the $\mathrm{pH}$ slowly increased over the remaining nine months, reaching slightly lower levels than during pre-injection $(<6.00$ in the west/southwest and $>6.00$ in the east/northeast of the site). Similarly, ORP values rapidly decreased from oxidizing conditions ( $>25$ millivolts or $\mathrm{mV}$ ) to reducing conditions $(<0 \mathrm{mV})$ during the first two months after the injection, and then rose to either slightly reducing conditions in the center of the site or slightly oxidizing conditions $(0-50 \mathrm{mV})$ around the perimeter of the site in the remaining months (Table S2).

\subsection{Mineralogical and Geochemical Analyses}

XRD analysis was conducted on the solid sediments that precipitated from the groundwater using the DIFFRAC.EVA software and the Crystallography Open Database (COD) for mineral identification. The XRD analysis showed that the solids from all wells were dominated by four minerals: pyrite (COD 5000151, 9000595, and 9000594), arsenian pyrite (COD 9013070 and 9013071), quartz (COD 9009666), and kaolinite (COD 1011045) (Figure S2). The arsenian pyrite was shown to exist as $\mathrm{As}_{0.026} \mathrm{FeS}_{1.974}\left(\mathrm{COD} 9013070\right.$ ) and $\mathrm{As}_{0.54} \mathrm{FeS}_{1.46}$ (COD 9013071). Arsenian pyrite was detected after one week of biostimulation, with $54 \%$ of the monitoring wells located near and downgradient of the injection wells showing evidence of arsenian pyrite formation. Arsenian pyrite was increasingly detected throughout the remaining nine months, with the peaks identified in $83 \%, 75 \%, 83 \%$, and $83 \%$ of the samples from one month, three months, six months, and nine months postbiostimulation, respectively.

In agreement with the XRD data, the XRF analysis revealed a strong presence of arsenic, iron, and sulfur with the precipitated biominerals (Figures S3 and S4). Arsenic was identified in all samples after one week of the injection, which persisted throughout the following nine months. Most of the wells also showed increases in iron or high iron counts over the experiment, with the relative amounts of arsenic to iron in the biominerals also increasing post-biostimulation. After one week of biostimulation, $62.5 \%$ of the samples depicted small arsenic peaks (defined as $<10 \%$ in relative arsenic counts to iron counts), while $37.5 \%$ had medium-large arsenic peaks $(>10 \%$ in relative arsenic compared to iron counts). These counts increased over the nine months to most of the samples (52\%) exhibiting medium-large arsenic peaks.

Electron microprobe (EMP) measurements were taken across two thin sections from one injection well and one downgradient monitoring well after two weeks and two months of the injection to observe the injectate's movement and determine the effectiveness of remediation. One injection well (I-3) was analyzed two weeks post-injection to observe temporal trends in arsenic sequestration at the injection site. Additionally, one monitoring well (RA-9) located $\sim 6.0 \mathrm{~m}$ downgradient of injection well I-3 was analyzed two months post-injection to ensure the successful migration of the injectate. Among 15 arsenian pyrite 
grains measured from each of the thin sections, the arsenic content ranged from 0.04 to $0.51 \mathrm{wt} \%$ arsenic. The average arsenic content in the precipitated grains analyzed was $0.19 \mathrm{wt} \%$ in the injection well two weeks post-biostimulation, while the average increased to $0.24 \mathrm{wt} \%$ in the monitoring well two months post-biostimulation.

\subsection{Imaging Analysis}

The scanning electron microscope (SEM) imaged gold-coated stubs and thin sections from injection well I-2 one week, two weeks, one month, three months, six months, and nine months following the injection. The pyrite grains throughout the experiment exhibited two morphologies: euhedral crystals 1-10 $\mu \mathrm{m}$ across and spherical aggregates of nanocrystalline pyrite (framboids) 5-30 $\mu \mathrm{m}$ in diameter (Figure 3a, Figures S5 and S6) [11,29]. Elemental mapping of these grains corroborates the EMP findings of the arsenian pyrite's heterogeneity (Figure 3b-d, Figures S7 and S8). Pyrite and arsenian pyrite first precipitated in the samples after two weeks, which increased in abundance after one month and persisted throughout the remaining months. Additionally, the arsenian pyrite framboids became increasingly consolidated over the nine months of bioremediation. These framboids also showed signs of weathering and increased biofilm surrounding the grains after three months, making it difficult to distinguish the arsenian pyrite from the abundant quartz grains. The pilot study by Lee et al. [11] showed that dry periods allowed the water table to drop and induced short-lived oxidation. The oxidation of metal sulfide has been shown to be slow without microbe-mediated reactions [37]. Limited weathering of biogenic pyrite observed over time suggests that sulfide oxidation has not been significantly catalyzed by $\mathrm{S}$ and $\mathrm{Fe}(\mathrm{II})$-oxidizing bacteria.
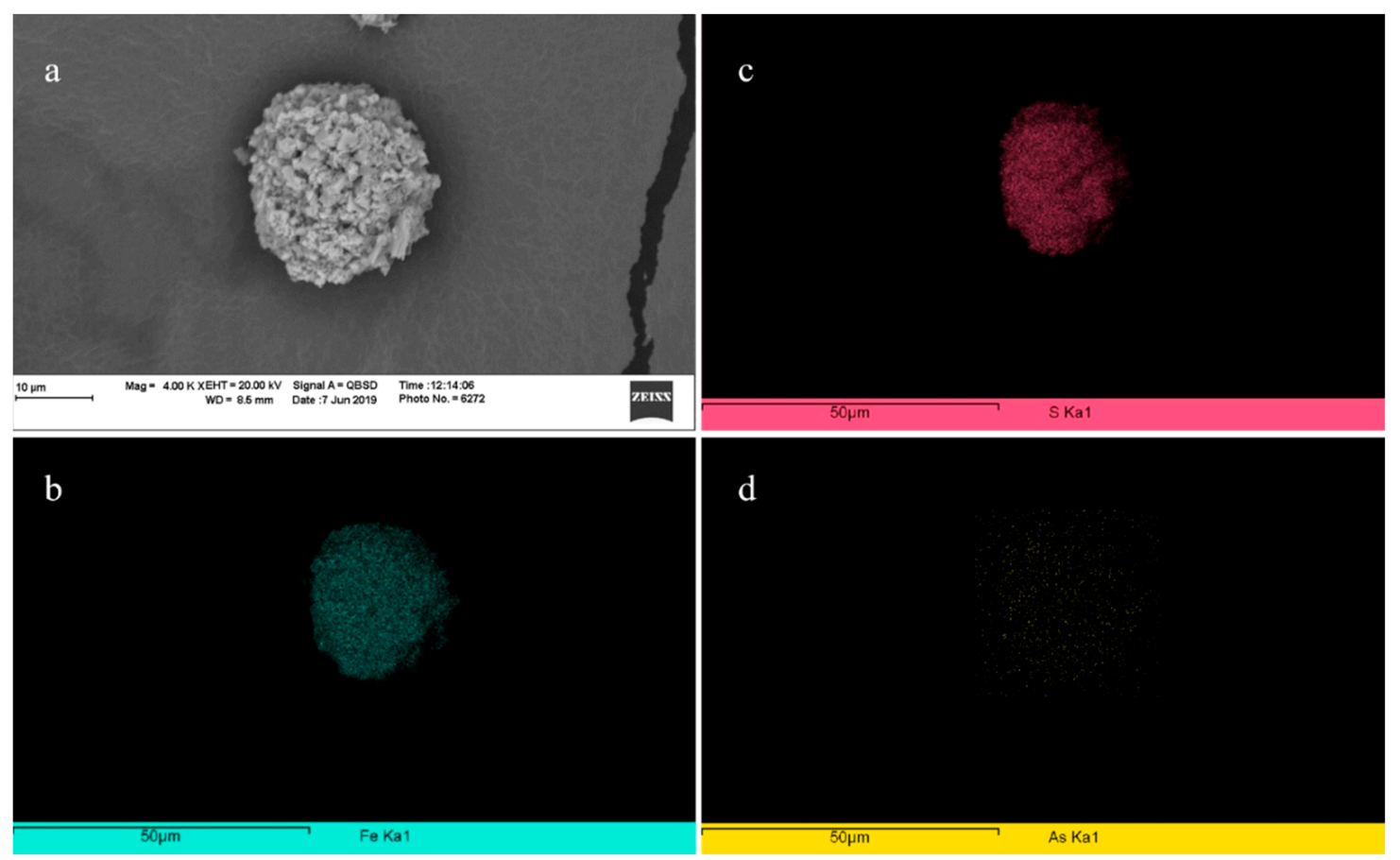

Figure 3. (a) SEM backscatter image of a $20-\mu \mathrm{m}$ arsenian pyrite framboid at $4000 \times$ magnification found in injection well I-2 one-month post-injection. (b-d) Elemental mapping of the arsenian pyrite framboid, demonstrating significant (b) iron and (c) sulfur concentrations present in a 1:2 ratio as well as sequestered (d) arsenic. Images from I-2 were included here, instead of monitoring wells, because they were of the best quality. These images from I-2 are representative of arsenian pyrite grains found in the monitoring wells.

The EMP also demonstrated the relative abundance of pyrite and arsenian pyrite grains throughout the experiment duration. Four gold-coated stubs from injection well I-2 were imaged one week, one month, six months, and nine months post-biostimulation 
(Figures S6 and S7). After one week, the backscatter images and elemental analyses depict only a small number of iron-rich grains, which contain little to no arsenic and sulfur (Figure S7). Yet, over the remaining nine months, Fe- and As-rich grains increased in abundance: After nine months, more than half of the sample was composed of Fe-rich grains that contained significant amounts of arsenic (up to $1.2 \mathrm{wt} \%$ ) and sulfur (Figure S8). These Fe-rich grains also had molar ratios of $\mathrm{Fe}$ and $\mathrm{S}$ around 1:2, which indicates that the precipitated solids were pyrite $\left(\mathrm{FeS}_{2}\right)$ or a pyrite-like mineral (Figure $\left.3 \mathrm{~b}-\mathrm{d}\right)$.

\subsection{Geochemical Modeling Analysis}

To determine the arrival of the injectate across the site after the initial injection, chloride present in the injectate to act as a conservative tracer. By applying Darcy's Law with the aquifer's average hydraulic conductivity of 400-500 m/y, hydraulic gradient of 0.010-0.015, and estimated porosity of $30 \%$, the average groundwater velocity at the site is approximately $20 \mathrm{~m} / \mathrm{y}$ [11]. Considering the groundwater velocity and the advective transport of chloride, the injectate was calculated to arrive at monitoring wells M-1, LH-10, and RA-9 (which lie downgradient of injection well I-1) after 30, 75, and 175 days, respectively (Figure 4; Table S7) [11]. Yet, the observed arrivals of the injectate, as determined from spikes in chloride measured in the wells, were 7, 30, and 180 days, respectively (Figure 4). The actual effective porosity is likely less than $30 \%$, which may explain why calculated arrival times of chloride tracer are greater than observed. Effective porosity (amount of interconnected pore space available for transmitting groundwater flow) is inversely proportional to travel velocity in porous media. A lower effective porosity would therefore produce a faster groundwater travel.

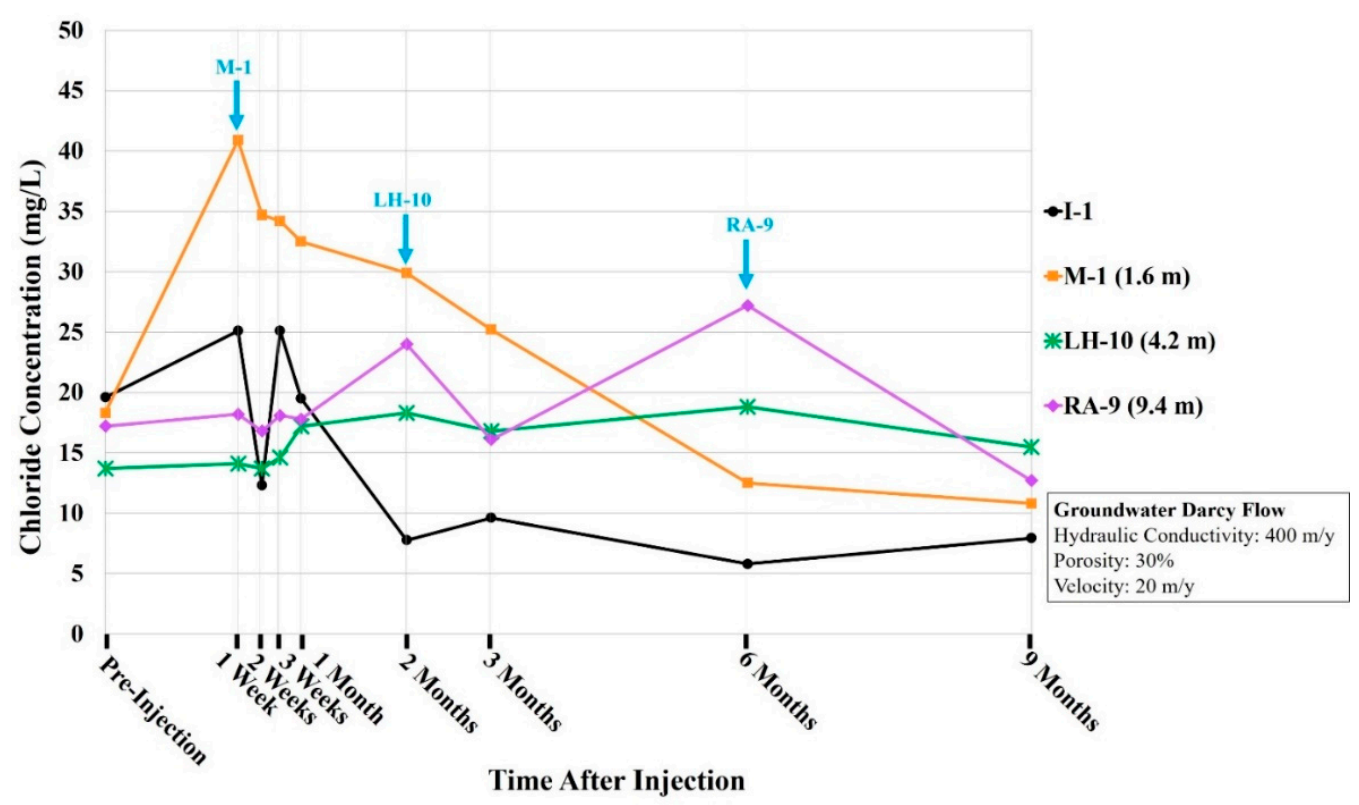

Figure 4. Breakthrough curves of chloride concentrations along in one injection well (I-1) and three monitoring wells (M-1, LH-10, and RA-9) over the nine months of bioremediation. Blue arrows represent the observed arrivals of chloride and the injectate in wells along the flow transect.

The study also needed to assess whether the decrease of arsenic in groundwater was due to its successful sequestration in arsenian pyrite or dilution from the injectate volume. To determine which scenario was correct, the fraction of removed arsenic was compared to the mixing ratio of the injectate and groundwater. The relative amounts of arsenic removed 
in each well during each sampling period were then compared to the pre-injection arsenic concentrations. The mixing ratio $(w)$ was calculated using

$$
w=\frac{C_{\text {mixed }}-C_{\text {pre-injection }}}{C_{\text {injectate }}-C_{\text {mixed }}}
$$

where $C_{\text {pre-injection }}$ is the chloride concentration in the groundwater prior to the injection, $C_{\text {injectate }}$ is the concentration in the injection mixture $(240 \mathrm{mg} / \mathrm{L})$, and $C_{\text {mixed }}$ is the concentration during a particular sampling period, likely due to the mixing of the injectate and the groundwater [11,29]. In the two representative monitoring wells of M-1 and LH-2, the arsenic removal fraction plateaus to $>0.80$ and $>0.90$, respectively, after two months and continues to moderately increase over the remaining months. The biggest difference between these wells is that the arsenic removal fraction immediately increases to 0.80 one week after the injection in M-1, while the removal fraction increases to 0.90 after two months in LH-2. The mixing ratios increase during the same time intervals as the arsenic removal fractions but remain low $(<0.12)$ in these wells over the nine months. After their initial increase, the mixing ratios decreased over the nine months, whereas the arsenic removal fractions continuously increased.

Additionally, to determine which iron sulfide or arsenic sulfide mineral would be preferentially precipitated from the injection, saturation indices of pyrite $\left(\mathrm{FeS}_{2}\right)$, arsenian pyrite $\left(\mathrm{FeS}_{1.99} \mathrm{As}_{0.01}\right)$, orpiment $\left(\mathrm{As}_{2} \mathrm{~S}_{3}\right)$, and realgar $(\mathrm{AsS})$ were calculated along the I-1 to RA-9 flow transect using the formulas noted in Table S7. For the five wells along the flow transect, all minerals were undersaturated in the groundwater prior to the injection (as indicated by a SI $<0$ ) (Figure 5a). After one week of biostimulation, I-1, M-1, and I-5 were calculated to be supersaturated in pyrite (as indicated by a SI $>0$ ), while LH-10 and RA-9 were supersaturated in pyrite after three weeks and two months, respectively. After two months, pyrite decreased in saturation, either remaining above saturation (I-1, M-1, and RA-9) or dropping below saturation (I-5 and M-1) after nine months. Arsenian pyrite follows similar trends in saturation as pyrite, with I-1, M-1, and I-5 showing arsenian pyrite supersaturation after one week (Figure 5a). However, LH-10 and RA-9 also were supersaturated in arsenian pyrite after one week. Furthermore, supersaturation was maintained in all wells throughout the remaining nine months, except for $\mathrm{M}-1$, which showed a slight undersaturation of arsenian pyrite after nine months (Figure 5a). Orpiment and realgar also follow similar trends as pyrite and arsenian pyrite: I-1, M-1, and I-5 were saturated with respect to orpiment and realgar after one week, while LH-10 and RA-9 became saturated after three weeks. Yet, both minerals' saturation levels dropped after three months, ending around 0 at the end of the experiment. After nine months, M- 1 was undersaturated in orpiment and realgar, I-1, RA-9, and I-5 had SIs around 0, and LH-10 was saturated in respect to both minerals.

Furthermore, GWB was used to model the geochemical reactions and conditions of the aquifer throughout the experimental procedure and determine which mineral (arsenian pyrite, orpiment, or realgar) would be preferentially precipitated. Before the injection, the models showed that the groundwater $\mathrm{pH}$ and redox potential (Eh) fell within the stability field of aqueous arsenous acid $\left[\mathrm{As}(\mathrm{OH})_{3}\right]$ (Figure $5 \mathrm{~b}$ ). After one month of bioremediation, the model predicted the Eh-pH measurements to fall within the stability field of solid arsenian pyrite, while after nine months, the measurements shifted to lie between the $\mathrm{As}(\mathrm{OH})_{3}$ and arsenian pyrite stability fields (Figure $5 \mathrm{~b}$ ). Orpiment and realgar were modeled to form only in the absence of iron. This Fe-free model revealed that the Eh-pH measurements fell primarily within the solid orpiment field after one month, which shifted to aqueous $\mathrm{As}(\mathrm{OH})_{3}$ after nine months. 


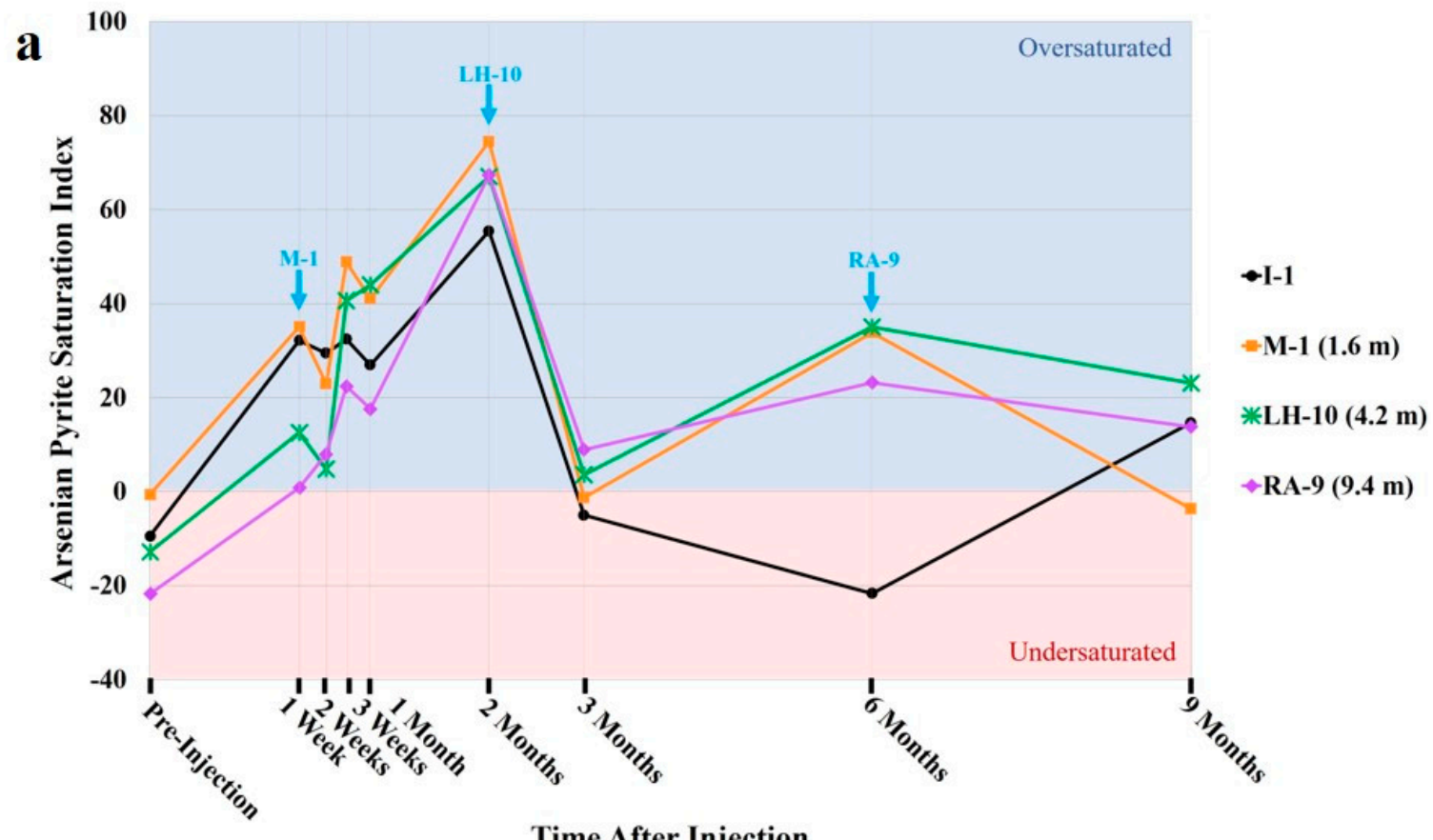

Time After Injection

b

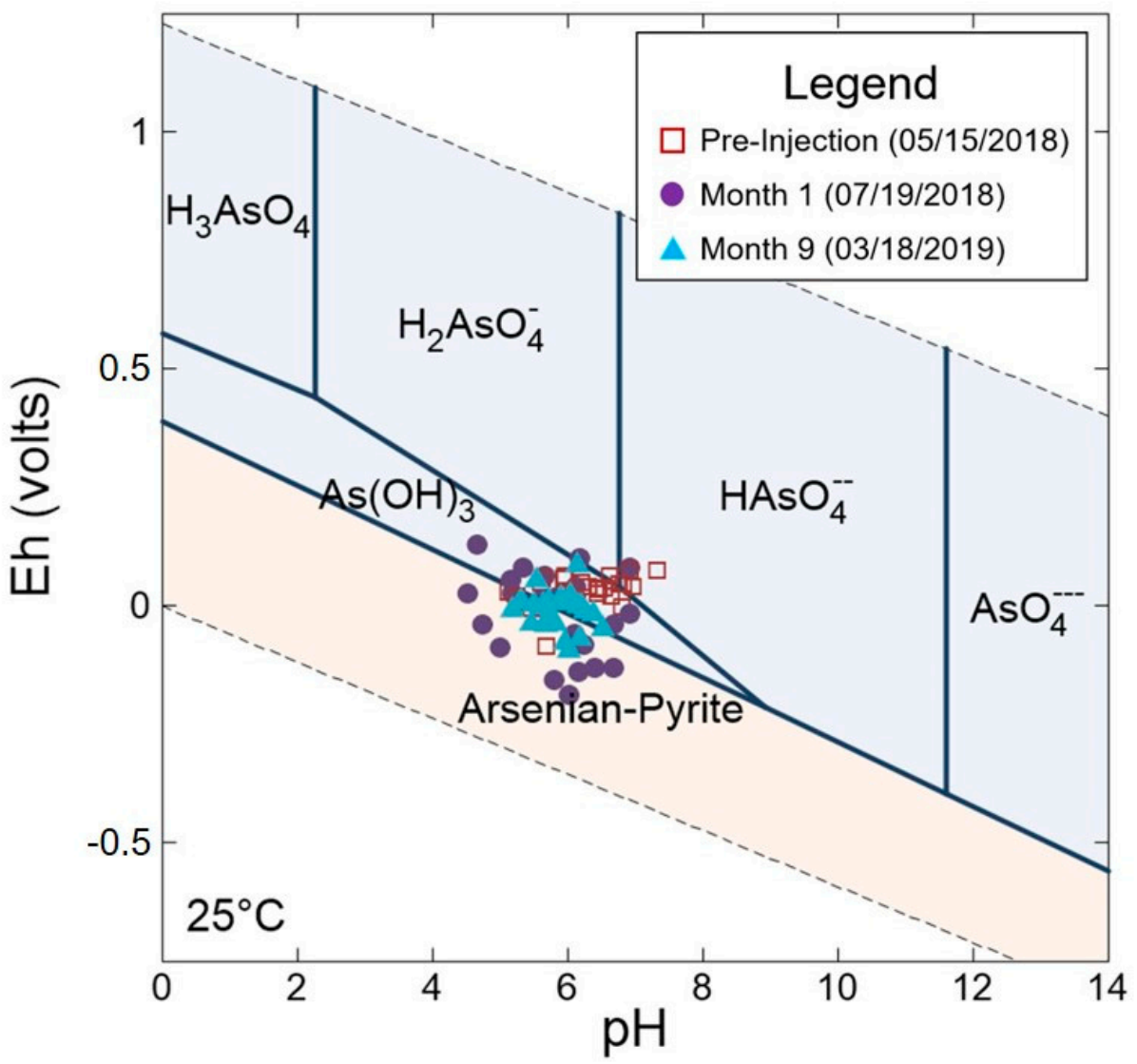

Figure 5. (a) Saturation index of arsenian pyrite plotted with the observed chloride tracer breakthrough curves along the I-1 to RA-9 flow path. Oversaturated values (SI >0) are shown in blue, while undersaturated values $(\mathrm{SI}<0)$ are shown in pink. (b) Eh-pH diagram of groundwater arsenic speciation in an As-Fe-S- $\mathrm{O}_{2}-\mathrm{H}_{2} \mathrm{O}$ system pre-injection, one-month post-injection, and nine months post-injection. The system was modeled at $25^{\circ} \mathrm{C}$ and atmospheric pressure $(1$ bar $)$, with fixed $\mathrm{As}(\mathrm{OH})_{4}{ }^{-}$, $\mathrm{Fe}^{2+}$, and $\mathrm{SO}_{4}{ }^{2-}$ activities of $10^{-4}, 10^{-3}$, and $10^{-3}$, respectively. The stability fields of solid minerals are shown in orange, whereas the stability fields of aqueous chemicals are shown in blue. 


\section{Discussion}

\subsection{Spatial and Temporal Concentration Analyses}

Based on the arsenic concentration changes following the injection, the study confirms the successfully precipitation and stabilization of arsenian pyrite throughout the bioremediation procedure. This study confirmed the findings of the previous study by Fischer et al. [26] that the decrease in arsenic at these wells reflect their distance from the injection wells, with the injectate taking longer to reach the wells located farther downgradient. Additionally, it was found that untreated groundwater entered the site and increased arsenic in the eastern and southern areas of the site after three months. Many injection wells (I-5, I-6, I-7, and I-11) were located upgradient along the eastern and southern margins of the site, and considering the general west/northwest flow of groundwater at the site, these wells were susceptible to recontamination from the influx of untreated groundwater. This untreated groundwater was oxidized based on the redox potential measurements, thus the change to oxidizing conditions may destabilize the arsenian pyrite and release arsenic back into the aqueous system. Furthermore, the injectate likely did not reach some wells (I-1, I-2, I-3, I-4, LH-5, and RA-12) as intended due to a limited flow path and that the injectate traveled only an approximate average of $15 \mathrm{~m}$ over nine months.

Yet, even while considering these three apparent trends in arsenic, the bioremediation procedure was holistically successful in capturing arsenic in the form of arsenian pyrite and reducing arsenic across the site. Fourteen wells that were above the site standard demonstrated decreases in arsenic due to bioremediation, with only eight of the wells remaining significantly above $0.05 \mathrm{mg} / \mathrm{L}$ after nine months. Furthermore, the plume in the northwest experienced significant reductions in size and arsenic concentration. These findings demonstrate the removal of groundwater arsenic due to SRB bioremediation and the subsequent formation of arsenian pyrite, as corroborated by Keimowitz et al. [14], Pi et al. [13], Lee et al. [11], and Berg et al. [38].

Furthermore, wells with fluctuating arsenic concentrations were important in identifying the need for multiple injections during the bioremediation procedure. Repeated injections of the ferrous sulfate mixture would maintain reducing conditions throughout the procedure [26]. The sustained reducing conditions would, in turn, stabilize the precipitated arsenian pyrite even with an influx of untreated, oxidizing groundwater. Repeated injections also increase the likelihood of the injectate reaching any wells that were missed due to variable groundwater flow [26]. Pi et al. [13] demonstrated the effectiveness of multiple injections. Regarding the aquifer in northwest Florida, this study would propose injecting at least every three months. This study found that after three months the arsenian pyrite framboids started to display signs of weathering and increased biofilm around the grains. This correlates to the influx of untreated groundwater onsite after three months, which began to degrade the arsenian pyrite in the upgradient eastern and southern areas of the site. The frequency of multiple injections may be identified by future research.

The sudden increase and steady decrease in iron and sulfate also verify the precipitation of arsenian pyrite. The increase in both ions after one week was caused by the ferrous sulfate injection, while their steady decrease over nine months demonstrates that the aqueous iron and sulfate were removed to precipitate pyrite. Aqueous arsenic was then adsorbed onto the pyrite, explaining the significant decrease in arsenic post-injection. The precipitation of arsenian pyrite is also indicated by the concurrent decreases of iron, sulfate, and arsenic, based on the following reaction [11]

$$
\mathrm{Fe}^{2+}+1.995 \mathrm{SO}_{4}{ }^{2-}+0.01 \mathrm{As}(\mathrm{OH})_{4}{ }^{-}+2 \mathrm{H}^{+} \rightarrow \mathrm{FeS}_{1.99} \mathrm{As}_{0.01}+1.02 \mathrm{H}_{2} \mathrm{O}^{+} 3.5 \mathrm{O}_{2}(\mathrm{aq})
$$

This reaction aligns with previously proposed chemical compositions of arsenian pyrite by Deditius et al. [39] [(Fe,As) $\left.\mathrm{S}_{2}\right]$ as well as with this study's XRD arsenian pyrite results $\left(\mathrm{As}_{0.026} \mathrm{FeS}_{1.974}\right.$ and $\left.\mathrm{As}_{0.54} \mathrm{FeS}_{1.46}\right)$. Furthermore, the EMP analysis from this study revealed that the pyrite forms in a molar ratio of total iron to total sulfur of approximately 
1:2. This molar ratio indicates that more sulfur, or sulfate, is consumed to produce arsenian pyrite, which is highlighted by the relative sulfate concentration decreases in the aquifer.

Similarly, decreases in $\mathrm{pH}$ and ORP corroborate the precipitation of arsenic pyrite in the site's aquifer. For pyrite to precipitate in aqueous conditions, the groundwater must be slightly acidic in $\mathrm{pH}(5.00-6.00)$ and reducing $[13,20]$. Before the injection, the aquifer was overall neutral in $\mathrm{pH}(>6.00)$ and oxidizing $(>25 \mathrm{mV})$ across the site, making it unsuitable for the formation of arsenian pyrite. Following the injection, the SRB mediated sulfate reduction engendered acidic $(<5.00)$ and reducing $(<0 \mathrm{mV})$ conditions throughout the site over the first two months, which then stabilized to slightly acidic values (5.00-6.00) in most of the wells, especially in the western and southern sections, and slightly reducing conditions throughout the center of the site and around the plume. The lowest ORP measurements were taken two months post-injection, during which most of the injectate was being transported downgradient across the site, which then increased over the remaining months from the influx of untreated oxidizing groundwater.

Overall, these findings confirm that the groundwater was thermodynamically suitable for the precipitation of arsenian pyrite throughout the nine months. Further field research is needed to understand how additional nutrients actually aid in arsenic sequestration effectiveness because phosphorus fertilizers may cause arsenic mobilization due to ionic competition for limited mineral sorbing sites [40-43].

\subsection{Mineralogical and Geochemical Analyses}

The mineralogical and geochemical analyses also confirm that the injection mixture engendered the formation of arsenian pyrite in the aquifer. The XRD analysis determined that the solid biominerals were primarily composed of pyrite, arsenian pyrite $\left(\mathrm{As}_{0.026} \mathrm{FeS}_{1.974}\right.$ and $\left.\mathrm{As}_{0.54} \mathrm{FeS}_{1.46}\right)$, quartz, and kaolinite. These identified compositions of arsenian pyrite closely match arsenian pyrite discovered by Rieder et al. [44] in a lignite sample in the Czech Republic. The XRD results also highlight an increase in arsenian pyrite detected over time: arsenian pyrite was detected after one week in $54 \%$ of the monitoring wells, which were located near the injection wells. After nine months, arsenian pyrite increasingly precipitated downgradient, with peaks being found in $83 \%$ of the wells located throughout the site.

The XRF analysis (Figures S3 and S4) discovered that the arsenic to iron ratio in the biominerals steadily increased over the nine months, indicating that higher amounts of arsenic were being sequestered through time. However, sulfur measured in the samples was uncharacteristically low for arsenian pyrite. Yet, the XRF's low detection of sulfur can be explained by its analytical settings: the Bruker XRF red filter was selected in this study because it is best suited for detecting heavy elements such as arsenic [35]. The red filter uses 14-40 keV X-rays to excite heavier elements above calcium (atomic number 20), including arsenic (atomic number 33) and iron (atomic number 26) [35]. Thus, the red filter cannot accurately measured sulfur (atomic number 16) in the samples.

The EMP analysis also verifies that groundwater arsenic was increasingly sequestered in iron sulfides such as arsenian pyrite. Using the EMP, the study assessed the performance of the bioremediation procedure by comparing the geochemical composition of samples that formed immediately after the injection to those from the middle of the experiment. The results demonstrated that the arsenic content in the arsenian pyrite grains ranged from 0.04 to $0.51 \mathrm{wt} \%$ arsenic, with the average arsenic content increasing from $0.19 \mathrm{wt} \%$ after two weeks to 0.24 wt \% after two months. Some iron sulfide grains also contained high amounts of arsenic ( $>0.50 \mathrm{wt} \%)$ after two months [30]. Overall, the XRD, XRF, and EMP geochemical results confirm the increased precipitation of arsenian pyrite as well as the increased sequestration of arsenic in arsenian pyrite over the nine months of SRB bioremediation. Limited weathering of biogenic pyrite observed over time implies that multiple injections of the remediating mixture may be needed, which would provide the SRB with a constant supply of organic carbon and electron acceptors for biostimulation and maintaining reducing conditions. 


\subsection{Imaging Analysis}

The EMP and SEM imaging results (Figures S5-S8) corroborate the geochemical analyses, with the images demonstrating the relative abundance of pyrite and arsenian pyrite over the nine months of bioremediation. Both the EMP and SEM found pyrite crystals and arsenian pyrite framboids (spherical aggregates of nanocrystalline pyrite) after two weeks, which increased and remained high in abundance throughout the nine months (Figure 3). Notably, the specific framboidal morphology of the arsenian pyrite observed in this study has been synthesized by Gartman and Luther [45] using ferrous iron and hydrogen sulfide. Their laboratory reaction engendered reducing conditions and the precipitation of arsenian pyrite framboids in less than $12 \mathrm{~h}$, aligning with this study's rapid precipitation of arsenian pyrite after exposure to the injectate [29,45]. More work is needed to determine the exact redox and biological conditions for these specific morphological changes. However, the consolidated framboidal arsenian pyrite highlight that under the right thermodynamic conditions (i.e., SRB activity and reducing conditions in groundwater), arsenian pyrite should rapidly precipitate and remain stabilized for an extended period of time, until the SRB deplete the system of ferrous sulfate and molasses.

\subsection{Geochemical Modeling Analysis}

The presence of chloride as a byproduct in the ferrous sulfate mixture helped pinpoint and explain the decrease in groundwater arsenic over the nine months. By looking at the observed chloride arrivals along the I-1 to RA-9 flow path, the monitoring wells located near the injection wells saw rapid reductions in arsenic during the first few weeks post-injection, while those located further downgradient saw decreases months after the injection. Monitoring well M-1, located $1.6 \mathrm{~m}$ downgradient from I-1, exhibited an immediate decrease in arsenic, with concentrations dropping from 0.08 to $0.02 \mathrm{mg} / \mathrm{L}$ in the first week. In contrast, LH-10 and RA-9 (located $4.2 \mathrm{~m}$ and $9.4 \mathrm{~m}$ downgradient of I-1) experienced significant decreases in arsenic after one and six months, respectively. The removal of arsenic in M-1, LH-10, and RA-9 correlate with the observed arrivals of the chloride tracer after 7, 30, and 180 days, respectively. Given these observations, the decrease in arsenic throughout the site coincide with the arrival of the remediating injectate.

However, the calculated arrivals of the chloride tracer do not completely align with the observed arrivals. The study calculated that the chloride would arrive at M-1, LH-10, and RA-9 after 30, 75, and 175 days, predicting that the injectate would arrive a few weeks later at M-1 and LH-10 and a few days earlier at RA-9 compared to the observed arrivals. These comparisons suggest that the calculation was inaccurate for monitoring wells near injection wells but relatively accurate for wells further downgradient along the flow path. As the calculations assume a constant hydraulic gradient, the inaccuracies may be the result of large hydraulic gradients around the injection wells: larger hydraulic gradients would increase the injectate velocity, which would explain the earlier-than-expected injectate arrivals at M-1 and LH-10 [11]. Additionally, diffusion and dilution of the tracer likely occurred while traveling downgradient, reducing the chloride concentration farther along the flow path [11]. This decrease in chloride would also explain the slightly delayed arrival of the injectate at RA-9 compared to the calculation.

Because the chloride tracer serves as a proxy for the injectate arrival, chloride also explains the trends exhibited in the arsenic removal fractions and mixing ratios. M-1, located $1.6 \mathrm{~m}$ downgradient of I-1, depicted that $80 \%$ of the groundwater arsenic was removed one week after the injection, and this removal rate was maintained for the remaining nine months of bioremediation. However, LH-2, which is approximately $6 \mathrm{~m}$ downgradient of the closest injection well I-5, saw an arsenic removal rate of $90 \%$ after two months, which was maintained for the remaining duration of the experiment. These arsenic removal trends were expected: The slow groundwater velocity $(20 \mathrm{~m} / \mathrm{y})$ along with the large hydraulic gradients, diffusion, and dilution allowed the injectate to swiftly arrive at nearby monitoring wells, while delaying its arrival at downgradient wells. Furthermore, although LH-2 received a smaller dosage of the injectate because of increased dilution 
downgradient, a similar percentage of arsenic was removed in LH-2 as in M-1. This finding reveals that even diluted amounts of the remediating mixture can remove significant amounts of arsenic, demonstrating that the remediation scheme effectively sequesters arsenic across both small and large distances from an injection point.

Moreover, the mixing ratios demonstrate that most of the dissolved arsenic was successfully sequestered by arsenian pyrite, rather than being reduced by dilution. During peak sulfate reduction after two months, LH-2 and M- 1 exhibited a $>94 \%$ and $>79 \%$ removal in arsenic. During the same timeframe, the mixing ratio of the chloride tracer was $<9 \%$ and $<6 \%$, respectively. Over the course of the experiment, $>80 \%$ of the arsenic was removed and sequestered in arsenian pyrite, while $<12 \%$ was removed by dilution. Couture et al. [46] also corroborate these findings, as they discovered that $50-80 \%$ of dissolved arsenic in sulfidic waters was removed due to the precipitation of pyrite.

Previous work has questioned the mineral responsible for arsenic sequestration after ferrous sulfate injection [13]. The results of this study revealed that before the injection, the four minerals had negative saturation indices, indicating that the groundwater conditions were unfavorable for their precipitation. However, after one week of bioremediation, I-1, $\mathrm{M}-1$, and I- 5 were supersaturated with these four minerals in the groundwater (as indicated by the positive saturation indices). For LH-10 and RA-9, pyrite reached saturation after three weeks and two months, respectively, whereas orpiment and realgar became saturated after three weeks. Despite all four minerals reaching saturation at some point during the bioremediation procedure, arsenian pyrite demonstrated preferred saturation at the site. All five wells (I-1, M-1, I-5, LH-10, and RA-9) showed supersaturation of arsenian pyrite after one week of bioremediation. Additionally, arsenian pyrite saturation in these wells was maintained over the nine months, with two exceptions: I-1 and M-1 dropped below saturation after six and nine months, respectively. Pyrite, orpiment, and realgar showed more inconsistency in their saturations over the nine months, dropping below saturation or hovering around saturation $(\mathrm{SI}=0)$ after three months of bioremediation. Considering these findings, the precipitation of arsenian pyrite was thermodynamically favored above these common iron and arsenic sulfide minerals during bioremediation, which is confirmed through the XRD and EMP analyses. Of these minerals, only arsenian pyrite and pyrite formed in the aquifer during the experiment, with arsenian pyrite being the dominant mineral present.

The modeled stability diagrams also corroborate the saturation indices, demonstrating the preferred precipitation of arsenian pyrite. The As-Fe-S and As-S models revealed that the $\mathrm{pH}$ and redox conditions of the groundwater before the injection were unsuitable for the precipitation of arsenian pyrite, orpiment, and realgar, with aqueous $\mathrm{AsOH}_{3}$ predicted as the dominant species pre-injection. However, due to SRB mediated sulfate reduction after the injection, the As-Fe-S model predicted that most of the arsenic would exist as arsenian pyrite after one month. The As-S model also showed that some of the arsenic could exist as orpiment, with an even smaller amount existing as realgar, after one month. Yet with the slight increase in redox potential (Eh) due to the influx of untreated groundwater, the models predicted that arsenic would likely exist as arsenian pyrite or $\mathrm{As}(\mathrm{OH})_{3}$ after nine months, with little potential for orpiment or realgar to form. Moreover, the As-S model that displayed orpiment and realgar excluded iron, which is inaccurate given the ferrous sulfate injectate would have introduced significant amounts of iron into the system. These results are further validated by Saunders et al. [25], who noted the thermodynamic favorability and spontaneity of arsenian pyrite precipitation in reducing aquifers, compared to orpiment and realgar that are likely unable to precipitate in low-temperature conditions. Given the model results and the thermodynamic conditions (i.e., a slightly acidic and reducing aquifer), arsenian pyrite was most likely to precipitate and remain stable in the system for several months. 


\section{Conclusions}

This study is one of the first to demonstrate multiple lines of evidence alongside field validation that supports long-term sequestration of groundwater arsenic using SRB bioremediation. This study builds upon proof-of-concept studies at the same industrial site, demonstrating full-scale remediation. The strong ferrous sulfate and molasses mixture provided the necessary amounts of iron, sulfate, and organic carbon for the SRB to form arsenian pyrite in an arsenic-contaminated aquifer at an industrial site. The geochemical and mineralogical analyses reveal the rapid precipitation of arsenian pyrite with excellent arsenic-adsorbing capability within two weeks. Additionally, calculations found that $>80 \%$ of the arsenic was sequestered in arsenian pyrite, reducing concentrations in many wells to below the site standard of $0.05 \mathrm{mg} / \mathrm{L}$ over the nine months. Yet, because arsenic levels slightly rose from short-term (one month) to long-term bioremediation (nine months), the study recommends repeated injections to maintain low arsenic levels. These critical findings demonstrate that the proposed method is an affordable and effective procedure for remediating arsenic in both industry settings and developing communities.

Supplementary Materials: The following are available online at https: / www.mdpi.com/article / 10.3390/min11050537/s1, Table S1: Groundwater $\mathrm{pH}$ versus collection date of samples; Table S2: Groundwater oxidation-reduction potential (ORP) $(\mathrm{mV})$ versus collection date of samples; Table S3: Dissolved oxygen (DO) (mg/L) versus collection date of samples; Table S4: Dissolved arsenic (mg/L) versus collection date of filtered groundwater samples; Table S5: Iron (Fe) (mg/L) versus collection date of groundwater samples; Table S6: Sulfate (SO4) $(\mathrm{mg} / \mathrm{L})$ versus collection date of groundwater samples; Table S7: Saturation indices (SI) calculations of pyrite, arsenian pyrite, orpiment, and realgar; Figure S1: Sand bags with black arsenic-bearing pyrite formed in wells; Figure S2: XRD peak positions of arsenian pyrite and pyrite; Figure S3: XRF spectrum of precipitated biominerals; Figure S4. XRF spectrum showing sulfur, iron, and arsenic peaks; Figure S5: SEM backscatter images of arsenian pyrite from I-2 over the experiment duration; Figure S6: SEM backscatter image of euhedral pyrite crystals three months post-injection; Figure S7: EMP backscatter images one week post-injection; Figure S8: EMP backscatter images nine months post-injection

Author Contributions: Conceptualization, M.-K.L., J.S. and J.R.; Methodology, M.-K.L., J.S. and A.F.; Software, A.F. and S.R.R.; Field sample acquisition, J.M., S.S. and A.F.; Formal analysis, A.F., M.M.R. and Z.M.B.; Investigation, A.F.; Writing-original draft preparation, A.F.; Writing-review and editing, M.-K.L., A.S.O. and S.R.R.; Visualization, A.F. and S.R.R.; Supervision, M.-K.L.; Funding acquisition, M.-K.L. and J.R. All authors have read and agreed to the published version of the manuscript.

Funding: This research was funded by the National Science Foundation (NSF-1425004, 526 NSF1642133) and our anonymous industrial partner.

Data Availability Statement: The data presented in this study are available in Fischer (2020) and Fischer et al. (2021) [26,30].

Acknowledgments: We would like to thank the financial support from the National Science Foundation (NSF-1425004, 526 NSF-1642133) and our anonymous industrial partner. Additionally, this research has greatly benefited by assistance from our colleague Bill Hames (Auburn University) in electron microprobe analyses.

Conflicts of Interest: The authors declare no conflict of interest.

\section{References}

1. WHO. Exposure to Arsenic: A Major Public Health Concern (2019 Revision); WHO: Geneva, Switzerland, 2019.

2. Agency for Toxic Substances and Disease Registry (ATSDR). Toxicological Profile for Arsenic; ATSDR: Atlanta, GA, USA, 2007.

3. Huerta-Diaz, M.A.; Morse, J.W. Pyritization of Trace Metals in Anoxic Marine Sediments. Geochim. Et Cosmochim. Acta 1992, 56, 2681-2702. [CrossRef]

4. Gong, Z.; Lu, X.; Ma, M.; Watt, C.; Le, X.C. Arsenic Speciation Analysis. Talanta 2002, 58, 77-96. [CrossRef]

5. Glodowska, M.; Stopelli, E.; Schneider, M.; Rathi, B.; Straub, D.; Lightfoot, A.; Kipfer, R.; Berg, M.; Jetten, M.; Kleindienst, S.; et al. Arsenic Mobilization by Anaerobic Iron-Dependent Methane Oxidation. Commun. Earth Environ. 2020, 1, 42. [CrossRef] 
6. Glodowska, M.; Stopelli, E.; Straub, D.; Thi, D.V.; Trang, P.T.K.; Viet, P.H.; AdvectAs Team Members; Berg, M.; Kappler, A.; Kleindienst, S. Arsenic Behavior in Groundwater in Hanoi (Vietnam) Influenced by a Complex Biogeochemical Network of Iron, Methane, and Sulfur Cycling. J. Hazard. Mater. 2021, 407, 124398. [CrossRef]

7. Kontny, A.; Schneider, M.; Eiche, E.; Stopelli, E.; Glodowska, M.; Rathi, B.; Göttlicher, J.; Byrne, J.M.; Kappler, A.; Berg, M.; et al. Iron Mineral Transformations and Their Impact on As (Im)Mobilization at Redox Interfaces in As-Contaminated Aquifers. Geochim. Et Cosmochim. Acta 2021, 296, 189-209. [CrossRef]

8. Woolson, E.A. Emissions, cycling and effects of arsenic in soil ecosystems. In Biological and Environmental Effects of Arsenic; Fowler, B.A., Ed.; Elsevier Ltd.: New York, NY, USA, 1983; pp. 51-139.

9. Smedley, P.L.; Kinniburgh, D.G. A Review of the Source, Behaviour and Distribution of Arsenic in Natural Waters. Appl. Geochem. 2002, 17, 517-568. [CrossRef]

10. Bencko, V.; Foong, F.Y.L. The History of Arsenical Pesticides and Health Risks Related to the Use of Agent Blue. Ann. Agric. Environ. Med. 2017, 24, 312-316. [CrossRef]

11. Lee, M.-K.; Saunders, J.A.; Wilson, T.; Levitt, E.; Ghandehari, S.S.; Dhakal, P.; Redwine, J.; Marks, J.; Billor, Z.M.; Miller, B.; et al. Field-Scale Bioremediation of Arsenic-Contaminated Groundwater Using Sulfate-Reducing Bacteria and Biogenic Pyrite. Bioremed. J. 2018, 23, 1-21. [CrossRef]

12. U.S. EPA. Organic Arsenicals; Notice of Receipt of Requests to Voluntarily Cancel or to Amend to Terminate Uses of Certain Pesticide Registrations; U.S. EPA: Washington, DC, USA, 2009; pp. 32596-32604.

13. Pi, K.; Wang, Y.; Xie, X.; Ma, T.; Liu, Y.; Su, C.; Zhu, Y.; Wang, Z. Remediation of Arsenic-Contaminated Groundwater by in-Situ Stimulating Biogenic Precipitation of Iron Sulfides. Water Res. 2017, 109, 337-346. [CrossRef]

14. Keimowitz, A.R.; Mailloux, B.J.; Cole, P.; Stute, M.; Simpson, H.J.; Chillrud, S.N. Laboratory Investigations of Enhanced Sulfate Reduction as a Groundwater Arsenic Remediation Strategy. Environ. Sci. Technol. 2007, 41, 6718-6724. [CrossRef]

15. Saunders, J.; Cook, R.; Thomas, R.; Crowe, D. Coprecipitation of trace metals in biogenic pyrite: Implications for enhanced intrinsic bioremediation. In Proceedings of the Fourth International Symposium of the Geochemistry of the Earth's Surface: Short Papers, Yorkshire, UK, 1996; Bottrell, S.H., Ed.; University of Leeds: Ilkley, UK, 1996; pp. 470-474.

16. Barton, L.L.; Tomei, F.A. Characteristics and activities of sulfate-reducing bacteria. In Sulfate-Reducing Bacteria; Barton, L.L., Ed.; Springer: Boston, MA, USA, 1995; pp. 1-32. [CrossRef]

17. Dyer, B.D. Field Guide to Bacteria; Cornell University Press: Ithaca, NY, USA, 2003.

18. Donald, R.; Southam, G. Low Temperature Anaerobic Bacterial Diagenesis of Ferrous Monosulfide to Pyrite. Geochim. Et Cosmochim. Acta 1999, 63, 2019-2023. [CrossRef]

19. Thiel, J.; Byrne, J.M.; Kappler, A.; Schink, B.; Pester, M. Pyrite Formation from FeS and $\mathrm{H}_{2} \mathrm{~S}$ Is Mediated through Microbial Redox Activity. Proc. Natl. Acad. Sci. USA 2019, 116, 6897-6902. [CrossRef] [PubMed]

20. Bostick, B.C.; Fendorf, S. Arsenite Sorption on Troilite (FeS) and Pyrite (FeS2). Geochim. Et Cosmochim. Acta 2003, 67, 909-921. [CrossRef]

21. Saunders, J.; Lee, M.-K.; Dhakal, P. Bioremediation of Arsenic-Contaminated Groundwater by Sequestration of Arsenic in Biogenic Pyrite. Appl. Geochem. 2018, 98, 233-243. [CrossRef]

22. DeFlaun, M.F.; Lanzon, J.; Lodato, M.; Henry, S.; Onstott, T.; Chan, E.W.; Otemuyima, B. Anaerobic Biostimulation for the In Situ Precipitation and Long-Term Sequestration of Metal Sulfides; Geosyntec Consultants: Tampa, FL, USA, 2009.

23. Onstott, T.C.; Chan, E.; Polizzotto, M.L.; Lanzon, J.; DeFlaun, M.F. Precipitation of Arsenic under Sulfate Reducing Conditions and Subsequent Leaching under Aerobic Conditions. Appl. Geochem. 2011, 26, 269-285. [CrossRef]

24. Saunders, J.A.; Lee, M.-K.; Wolf, L.W.; Morton, C.M.; Feng, Y.; Thomson, I.; Park, S. Geochemical, Microbiological, and Geophysical Assessments of Anaerobic Immobilization of Heavy Metals. Bioremed. J. 2005, 9, 33-48. [CrossRef]

25. Saunders, J.A.; Lee, M.K.; Shamsudduha, M.; Dhakal, P.; Uddin, A.; Chowdury, M.T.; Ahmed, K.M. Geochemistry and Mineralogy of Arsenic in (Natural) Anaerobic Groundwaters. Appl. Geochem. 2008, 23, 3205-3214. [CrossRef]

26. Fischer, A.; Lee, M.K.; Ojeda, A.S.; Rogers, S.R. GIS Interpolation Is Key in Assessing Spatial and Temporal Bioremediation of Groundwater Arsenic Contamination. J. Environ. Manag. 2021, 280, 111683. [CrossRef]

27. Mintz, J.; Miller, J. Lynn Haven Retired Substation Remedial Action Plan; 1983.

28. Schmidt, W.; Clark, M.W. Geology of Bay County, Florida (No. 57); Bureau of Geology, Florida Department of Natural Resources: Tallahassee, FL, USA, 1980.

29. Wilson, T.J. Pyrite Biomineralization and Arsenic Sequestration at a Florida Industrial Site: Imaging and Geochemical Analysis. Master's Thesis, Auburn University, Auburn, AL, USA, 2018.

30. Fischer, A.B. Field and Laboratory Investigations of Groundwater Arsenic Sequestration in Biogenic Pyrite at an Industrial Site in Florida. Master's Thesis, Auburn University, Auburn, AL, USA, 2020.

31. Ben-Dov, E.; Brenner, A.; Kushmaro, A. Quantification of sulfate-reducing bacteria in industrial wastewater, by real-time polymerase chain reaction (PCR) using dsrA and apsA genes. Microb. Ecol. 2007, 54, 439-451. [CrossRef]

32. Rajaković, L.V.; Todorović, Ž.N.; Rajaković-Ognjanović, V.N.; Onjia, A.E. Analytical Methods for Arsenic Speciation Analysis. J. Serb. Chem. Soc. 2013, 78, 1461-1479. [CrossRef]

33. Rasul, S.B.; Munir, A.K.M.; Hossain, Z.A.; Khan, A.H.; Alauddin, M.; Hussam, A. Electrochemical Measurement and Speciation of Inorganic Arsenic in Groundwater of Bangladesh. Talanta 2002, 58, 33-43. [CrossRef]

34. Bruker Tracer Series User Guide: Hand-Held XRF Analyzers; Bruker: Billerica, MA, USA, 2010; pp. 169-232. 
35. Reed, S.J.B. Electron Microprobe Analysis and Scanning Electron Microscopy in Geology; Cambridge University Press: Cambridge, UK, 2005; ISBN 9780521848756.

36. Bethke, C.M. Geochemical and Biogeochemical Reaction Modeling; Cambridge University Press: Cambridge, UK, 2008.

37. Baker, B.J.; Banfield, J.F. Microbial communities in acid mine drainage. FEMS Microbiol. Ecol. 2003, 44, 139-152. [CrossRef]

38. Berg, J.S.; Duverger, A.; Cordier, L.; Laberty-Robert, C.; Guyot, F.; Miot, J. Rapid pyritization in the presence of a sulfur/sulfatereducing bacterial consortium. Sci. Rep. 2020, 10, 1-13. [CrossRef] [PubMed]

39. Deditius, A.P.; Utsunomiya, S.; Renock, D.; Ewing, R.C.; Ramana, C.V.; Becker, U.; Kesler, S.E. A Proposed New Type of Arsenian Pyrite: Composition, Nanostructure and Geological Significance. Geochim. Et Cosmochim. Acta 2008, 72, 2919-2933. [CrossRef]

40. Neumann, R.B.; Ashfaque, K.N.; Badruzzaman, A.B.M.; Ashraf Ali, M.; Shoemaker, J.K.; Harvey, C.F. Anthropogenic Influences on Groundwater Arsenic Concentrations in Bangladesh. Nat. Geosci. 2010, 3, 46-52. [CrossRef]

41. Gao, X.; Wang, Y.; Hu, Q.; Su, C. Effects of Anion Competitive Adsorption on Arsenic Enrichment in Groundwater. J. Environ. Sci. Health Part A 2011, 46, 471-479. [CrossRef] [PubMed]

42. Gao, X.; Su, C.; Wang, Y.; Hu, Q. Mobility of Arsenic in Aquifer Sediments at Datong Basin, Northern China: Effect of Bicarbonate and Phosphate. J. Geochem. Explor. 2013, 135, 93-103. [CrossRef]

43. Aziz, Z.; Bostick, B.C.; Zheng, Y.; Huq, M.R.; Rahman, M.M.; Ahmed, K.M.; Geen, A. van Evidence of Decoupling between Arsenic and Phosphate in Shallow Groundwater of Bangladesh and Potential Implications. Appl. Geochem. 2017, 77, 167-177. [CrossRef] [PubMed]

44. Rieder, M.; Crelling, J.C.; Šustai, O.; Drábek, M.; Weiss, Z.; Klementová, M. Arsenic in iron disulfides in a brown coal from the North Bohemian Basin, Czech Republic. Int. J. Coal Geol. 2007, 71, 115-121. [CrossRef]

45. Gartman, A.; Luther, G. Comparison of Pyrite $\left(\mathrm{FeS}_{2}\right)$ Synthesis Mechanisms to Reproduce Natural FeS 2 Nanoparticles Found at Hydrothermal Vents. Geochim. Et Cosmochim. Acta 2013, 120, 447-458. [CrossRef]

46. Couture, R.M.; Gobeil, C.; Tessier, A. Arsenic, iron and sulfur co-diagenesis in lake sediments. Geochim. Cosmochim. Acta 2010, 74, 1238-1255. [CrossRef] 